\title{
"Race or Ethnic Group?" Politics of Race in Malaysia
}

\author{
Rie Nakamura \\ College of Law, Government and International Studies, Universiti Utara Malaysia, Malaysia
}

Copyright $(\mathcal{C} 2015$ by authors, all rights reserved. Authors agree that this article remains permanently open access under the terms of the Creative Commons Attribution License 4.0 International License

\begin{abstract}
This paper investigates the reasons why university students in Malaysia prefer the term race over ethnic groups. The usage of the word race by students and faculty members in the classroom will be examined, along with academic writings and media usages of this term. Further, reasons for the pervasiveness of the term race in Malaysia will be explored. In this paper I argue that the concept of race is used to create a notion that the three major ethnic groups in Malaysia are physically/biologically separate groups, and that their differences will never be changed. Such sedentary ethnic divisions are important for the maintenance of social hierarchy and status quo in Malaysia.
\end{abstract}

Keywords Race, Racial Discourse, Bumiputera, Ethnic Groups, Colonialism

\section{Introduction}

This is an examination of the word race as used in Malaysia. This paper was thought out of my frustration in teaching at one of the national universities in Malaysia. Many students who took my course had problems with understanding the concepts of race and ethnic groups. Although the concept of race was discussed as a problematic concept without any scientific basis, and the students were told that anthropology and other disciplines in humanity and social sciences have abandoned this concept, most of my students used the term race persistently throughout my course.

This paper is an attempt to understand the reason why in Malaysia the word race is preferred over the more widely accepted term ethnic groups and ethnicity to describe different groups in academia. Firstly, I examine how students used the word race in their coursework, and how faculty members and other scholars (including anthropologists) use the word race. I then examine the term race in Malaysia historically. I compare racial discourse which was introduced and spread under British colonial domination with contemporary racial discourse. Finally I explore the reasons for the pervasive usage of race in
Malaysia, and argue that the concept of race is useful to create the notion that the three major ethnic groups in Malaysia - Malays, ethnic Chinese and ethnic Indians - are separate groups and that their differences will never be changed. Such fixed divisions are important for Malaysia where every aspect of the citizen's life is based on ethnic divisions. The concept of race therefore supports ethnic hierarchy and status quo.

Various methodologies were applied to conduct this research. For understand the usage of race in class room, predominantly participant observation was used which also includes analysis of students assignments, discussions and informal interviews. A brief survey of race and ethnic groups was carried out amongst the students who were taking my course and faculty members of College of Law, Government and International Studies, Northern University of Malaysia. Text analysis was used to understand the usage of race in academic publications including a textbook for the course on ethnic relations, newspaper articles, pre-colonial writings and the British Colonial writings on their local subjects.

\section{2. "Race" in the Classroom}

When I asked students to explain different ethnic groups in Malaysia, they often referred to physical appearance, especially skin color in their explanation: "Malay people have olive color skin" or "Chinese people have fair skin". Skin color is significant in ethnic identity. It is generally agreed that the ethnic Chinese have the fairest skin, and they are followed by darker Malays and the darkest ethnic Indians. Ethnic identity is frequently linked to the tone of one's skin. I was once told by a student that I do not look Japanese since I am "too dark" to be Japanese. Ethnic Indian students have remarked about their experiences, recounting feelings of discrimination by others because of their skin color. One student described an incident during which an ethnic Chinese pupil who had forgotten her sportswear refused an offer from an ethnic Indian pupil to rent her sportswear because the ethnic Chinese pupil was scared her skin would turn darker. Within the ethnic Indian community, fair skin is also seen as positive and preferred. Willford discussed how fair skinned 
women are preferred amongst the ethnic Indian community and marriage to fair skinned women is a source of pride to men $(1, \mathrm{p} 205-8)$.

I found that a considerable number of Malay students are from mixed ethnic backgrounds, with mixed parentage from groups like Javanese, Bugis, Arab, Minangkabau, Chinese, Indian, and so on. Those who mentioned about the mixed ethnic background further indicated their awareness of their physical differences from so-called "pure" Malay. They believe that they are mistaken for other ethnic groups since they do not look "typically Malay" due to their skin color, the shape of their face, eyes, nose and so forth. Despite the fact that they see ethnic groups as cultural groups, when they identify other's ethnic background, physical appearance is the main measurement to classify others in Malaysia.

The confusion of the concepts of race and ethnic groups is also found in the teaching materials for a course called Ethnic Relations. With widespread discussion of ethnic relations in $2007(2$, p8) the Ministry of Higher Education under the Prime Minister Abdullah Badawi made Ethnic Relations a compulsory course to be taught in all Malaysian universities (3, p197). The aim of having this course compulsory to all the students in universities is to facilitate interaction amongst different ethnic groups and to promote better understanding amongst them (2, p8-9).

According to Shamsul A. B. who was appointed as the general editor of the textbook ${ }^{1}$ used in this course, the textbook was a publication that "had received so much attention from the Cabinet", "in the history of post-colonial Malaysia" (2, p9). It was made under exceptional attention of the cabinet. Each draft was sent to the cabinet for review, and the cabinet reviewed it at least 3 times. The originally the draft was 350-page long but it was compressed to 150-page at the end (2, p9-10).

I found some problems in the usage of the term race in this textbook. The chapter mentions differences between race and ethnicity as followings:

- During the $19^{\text {th }}$ century in Europe, ethnicity is seen as similar to race (humans were grouped according to physical characteristics like skin color, body skeleton, head shape and hair texture).

- According to Banton's study on historical development of the concept of race, there are three theories to classify human being by biological differences; 1) race as lineage, 2) race as type and 3) race as subspecies.

- Sociologists say that race concept is a result of social construction

- Race is a group of people that see themselves and is seen by others as having their own lineage that differs them from others.

The contemporary view on the race concept is that it is a system for biologically categorizing human beings. It was established during late eighteenth to early nineteenth centuries when Europe expanded its hegemony to other parts of the world, and was utilized to legitimize their domination over others. Though the Ethnic Relations course indicates that race is a social construct, it does not further explain this in the context of colonialism. The description of race as lineage group further confuses students about the concepts of race and ethnic groups.

For the definition of ethnicity, the course emphasizes both objective and subjective aspects of identity. The objective aspects involve culture, language, religion, tradition, dress, foods, and even hair style, while the subjective aspects indicate group feelings, shared beliefs, origins and lineage. The course defines ethnic groups as cultural groups ${ }^{2}$ and differentiates them from racial groups. Yet when it refers to ethnic minorities, the concept of race is predominant: "minorities [sic] refer to social groups (which are) oppressed because of ethnic character, biology, etc". The course quotes Kinloch in order to explain the four aspects of minority groups, which are physical, cultural, economical and behavioral aspects. For the physical aspects, issues of race, gender and age groups are discussed. With regards to cultural aspects, religion and ethnicity are discussed, while for economic aspects social classes are concerned, and for the behavioral aspects "deviant behaviors" are mentioned (4). These definitions indicate that there are physiological differences between minority and majority people and one can "see" divisions between minority and majority groups. In the course subsection called prejudice, the word race is used interchangeably with the term ethnic group. The lack of critical analysis of the concept of race and the indifference toward the historical development of this concept has resulted in confusion over the terms ethnic and race amongst Malaysian university students.

The confusion about these concepts is further observed amongst faculty members. Questionnaires were distributed to faculty members in one college to gauge understandings of the concepts of race and ethnic groups. There was only one faculty member who clearly stated that the concept of race is irrelevant. One of the faculty members complained that the survey questions were confusing and there should be a clear definition of race and ethnic group stated at the beginning of the questionnaires. There is a general sense of confusion about the terms race and ethnic groups in higher education.

The survey was initially distributed amongst university students, and later the same questionnaires were distributed amongst the faculty members for a comparison. A list of different groups was provided and students were asked if they think that the group that they identify with was a racial group or an ethnic group. The survey result revealed a tendency amongst the students to see the major ethnic groups of Malaysia - Malay, ethnic Chinese and ethnic Indian - as racial groups, while they view the indigenous people of Sabah and Sarawak, non-Malay indigenous people, and other minorities as ethnic groups. The students' responses reflected those from faculty members in identifying racial groups and ethnic groups although faculty members' response was limited ${ }^{3}$. 


\section{Race and the Term Ethnic in the Media}

I have examined newspaper articles in English ${ }^{4}$ published in Malaysia since 1975 by using the online Bernama News archive. 984 articles contain the term racial in their heading, while 268 articles had the term ethnic ${ }^{5}$. The majority of the race articles discussed issues of national integration, racial unity, efforts to decrease racial sentiment and the eradication of racial antagonism. The races discussed in these articles predominantly imply the three major ethnic groups -Malay, ethnic Chinese and ethnic Indian. One article on the civil service indicated a need for multi-racial civil servants from Malay, ethnic Chinese and ethnic Indian groups. One article on university life indicated a lack of integration amongst the three major ethnic groups. Another article concerning the National Service Program talked about the lack of participation of ethnic Chinese youth in comparison to Malay and ethnic Indian groups, to list a few examples. The word race also connotes something negative. For example, "don't raise issues that can incur racial wrath", "do not stoke racial tensions", "do not vote along racial lines" or "do not attempt racial politics". Similarly, headlines such as "don't play up racial issues for political mileage" can be seen, along with "don't create racial tension", "do not tinkle with racial politics", "do not exploit racial issues to seek popularity", "do not stir up racial sentiment" or "do not harp on racial and religious sentiments", and so forth.

The word ethnic was used in reference to the cultural differences between groups, including literature, music, dance, dress, foods, jewelries, crafts, traditions, festivals and so on. The word exotic was found to accompany the word ethnic on several occasions. Since the Ministry's Ethnic Relations course was also one of the frequent topics, the articles related to education used the term ethnic. The term was also used to talk about the people of Sabah and Sarawak, as well as ethnic minorities including orang asli ${ }^{6}$ none-Malay indigenous people. Considerable numbers of articles also used the term race along with ethnic which indicates that two terms are considered to be the same.

It can be summarized that the Malaysian media tends to use the word race when reporting about national integration, policies and interrelationships between the three major ethnic groups, while they tend to choose the word ethnic when discussing about the peoples in Sabah and Sarawak and cultural issues. The tendency of the usage of race and ethnic in the media is similar to the tendency found amongst university students and faculty members.

\section{4. "Race" in Academic Writings}

In the fields and subfields of social sciences it widely agreed that the concept of race to classify and analyze particular groups of people has no scientific foundation and the concept of race has been rejected as an analytical concept ${ }^{7}$. The dominant concern of race studies has been on the process of constructing race as a social reality or the survival of race as a concept through the $21^{\text {st }}$ century $(5-6 ; 7$, p51-63; 8-9).

In Malaysia, however, the term race is widely used in academic writings as an accepted "scientific" concept to discuss ethnic relations. For instance, Syed Husin Ali, a trained anthropologist, completed his Ph.D. at the London School of Economics and served as a professor of anthropology for many years at the University of Malaya, reflected his belief in race in his recent publication on ethnic relationship in Malaysia. In this book, he stated that the concerned groups, such as Malay, ethnic Chinese, ethnic Indian and so on should be referred as ethnic group rather than racial group. One of the four explanations ${ }^{8}$, he gave was that all so called racial group in Malaysia belong to the same racial stock, namely Mongoloid. Thus it is different from the situation in countries like the USA or South Africa where Caucasoid race and Negroid race exist. He argued that "ethnic relations in Malaysia have its own character, quite different from that existing in other countries" $(10, \mathrm{p} 1)$. His explanation indicates that race is a legitimate scientific term to classify human population. It has to be noted that three racial groups, he listed Mongoloid, Caucasoid and Negroid, originated from Johann Friedrich Blumenbach's classification of human race in the $18^{\text {th }}$ century. Blumenbach's classification had great impact on development of racial studies, and it has been widely accepted and pervasive amongst the people through education. Yet, examination of racial categories in various fields have proven that there is no scientific ground to group human populations based on their physical appearance as Blumenbach did $(5 ; 9)$.

The ethnic conflicts after the national election usually referred to as the 13 May incident of 1969, is often called a racial riot or a racial clash. In Ye Lin-Sheng's The Chinese Dilemma, written in response to former Prime Minister Mahathir's The Malay Dilemma, the term race was deliberately used. Ye explained that the term ethnic group was indeed "more fashionable" than the term race, and the term race should be avoided due to the racist acts committed especially during World War II. However, calling himself non-academic, Ye preferred to use the term race since he simply found the word "clearer" $(11, \mathrm{p} 3)$. Unfortunately Ye did not further explain what was meant by race as a "clearer term", but it can be assumed that the term race, which focuses on the external labeling of people, is much easier to handle and to compartmentalize the population into distinguished categories than the term ethnic, which indicates a more complex, fluid and malleable identity of people. Ye probably found that the term race is suitable when talking about the fixed social positions of the three major ethnic groups (Malay, ethnic Chinese and ethnic Indian) in Malaysia.

Syed Husin Ali's usage of the term race was crosschecked against a sample of theses written by Malaysian students who received graduate degrees in the West. It was found that most of the theses used the term ethnic groups rather than 
race, however Sundram's Master thesis at Michigan State University discussing the class relationship in Malaysia purposively used the word race. Sundram stated that this term was used in order to discuss social stratification of the three major ethnic groups in Malaysia, arguing that race is a social construction, yet "once racial categorization takes on a particular configuration within a society on an everyday level" (12, p29) it has become reality. Racial groups are stratified along class differences and have their own goals and interests, which might cause conflicts (12, p30).

I believe Sundram chose the term race to discuss class differences in Malaysia because the term itself embodies power relationships. According to Banton, those who study racial relations using class analysis view the concept of race as a signifier or symbol of social conflicts. Furthermore, stated that race uses biological differences to exclude others from privilege $(7, \mathrm{p} 186,99)$. The reason for the pervasiveness of the concept of race in academic discourses seemed to be the nature of ethnic relationships in Malaysia, and its way of constructing the nation-state.

\section{Introduction of Race to Malaysia}

The word equivalent to race in the Malay language is bangsa. Looking at the development of the word bangsa, it is both polysemous and ambiguous. Milner argues that bangsa Melayu is a concept that was invented during the $19^{\text {th }}$ century. He examined the etymology of the term and demonstrated how the word originally meant genealogy, lineage and family, and then developed into something equivalent to the ethnic group which was used to group people based on their origin, customs and religion (13-15). Further, Milner explains how the term bangsa developed to the notion of nation $(14, \mathrm{p} 51,68-9,100,106)$

According to Hirschman the notion of race, which is an attempt to differentiate people biologically, was brought into Malaysia by the British colonial administration. By examining the development of ethnic classifications in the censuses during the British colonial era, Hirschman found that modern censuses are different from the census conducted previously. It was essentially a $19^{\text {th }}$ century phenomenon that all of the population had to be categorized and "'invented' from experience and common knowledge" $(16, \mathrm{p} 561)$. The word nationalities was used in the earlier census, but this word was replaced by the term race because this term is "a wider and more exhaustive expression than "nationality"' $(16, \mathrm{p} 561)$. However the officials did not seem to have a clear understanding of this term. The term race had become dominant in the census because it was armed with the scientific theory of race, namely Social Darwinism. Different races had reflected different levels of progress or evolutionary stages. This "scientific" theory provided legitimacy to British to justify its colonial dominance as a superior race. Hirschman argued that the changes of census categorization reflect the changes in European racial beliefs and their imperial role (16, p568).
British colonial administration utilized local political systems for their colonial management and developed paternalistic attitudes toward Malays, as if "a father dealing with his children" (17, p342). Malays have been portrayed as docile, loyal and dependent people who have a weak intellectual capability, and the well-known stereotype of Malay people was their indolence or laziness. For ethnic Chinese people, the British considered them to be more industrious, hardworking and capable, and developed sense of resentment and fear of the Chinese as thieves, which could be a threat to the British economic establishment. Ethnic Indian people were considered as cheap and docile laborers, much easier to control in comparison to the ethnic Chinese, and they filled the labor shortage in plantations (17, p346-7). As landless plantation workers, they formed the lower strata of British Malaya.

Syed Hussein Alatas argued that such stereotypes of three ethnic groups were result of expansion of "colonially controlled urban capitalist economic activities" (18, p80). As subsistence farmers, Malays were unwilling to participate in colonial capitalistic economy while ethnic Chinese and Indian became important labors to support the colonial capitalism (18). Application of the race concept to the local population made such stereotypes of local populations based on the colonial perception as biologically determined characteristics of the local population.

Neither Hirschman nor Milner explicitly discussed how the scientific classification of race, mostly expressed as physical appearance, has penetrated people's minds and become a social reality in Malaysia. However, two school textbooks widely read by students of British Malaya, Hikayat Abdullah and Hikayat Dunia, were examined by Milner in the Invention of Politics in Colonial Malaya. This gives us an idea how British created education played a role in the propagation of the concept of race. Milner's in-depth analysis of these two texts indicates that there was the origin of the notion of bangsa as nation-state, in which the nation-state is considered as territorial political unit and humans are understood as members of nation-state and also different races $(14$, p93, 95, 290).

In Hikayat Abdullah, written by Munshi Abdullah" there are description of the slave women who were predominantly Balinese and Bugis:

When I reached the boat, I found it full of slaves ... When I went down inside I saw many women, some mere girls, some adolescent and other already grown up. Some were fair, other dark. They were all shades of colour. There were some who did not understand Malay, with frizzy hair and black faces. Only their teeth showed white. They had fat stomachs and thick lips (19, p183-4).

Abdullah mentioned the skin color, hair texture, facial features and body shape which echoed descriptions found in the writings of European officers of their colonial subjects. For instance, Sir Richard Winstedt, an Oxford educated colonial civil servant in British Malaya and later president of 
Raffles College in Singapore from 1921-31, wrote the following:

The Malay of today, a broad-headed individual with olive skin, fine eyes, a neat well-proportioned body, lank black hair and almost hairless chin, is the primitive Malay plus many foreign strains derived from marriage with Chinese from Chou times down to the advent of Islam, with Hindus of the Deccan and Bengal, with Muslim Indians, Siamese and Arabs (20, p16)

For comparative purposes, the following is an extract from one student's assignment on orang asli written in 2009. This student probably found descriptions of orang asli in some writings, yet she decided to include descriptions of physical appearance. Indeed, her gaze was very similar to that of Winstedt as he casted his eyes toward his colonial subjects.

The geometrical measure of Semang for the men's height is about $153 \mathrm{~cm}$ and for the women is about $142 \mathrm{~cm}$. Their skin color is dark or black, the shape of the head is round and long, the forehead is low and rounded and over the root of the nose, which is short and depressed. The eyes are often wide open and round, even at times showing no obliquity.

According to Milner Malay people did not have a notion of grouping people by race prior to European domination. For instance, in the Malay sultanates' historical accounts, Sejarah Melayu or Malay Annals, the word bangsa was only used once (21, p85). In the English translation of Sejarah Melayu by Leyden, the word race is used more than once, however there is no physical description of people as we see in the colonial writings. When it talked about beautiful princess, it did not mention about her skin color, shape of her eyes, or nose. For instance, a beautiful daughter of a raja (king) was described as follows:

This Raja Kida Hindi had a daughter extremely beautiful and handsome, whose face glittered and shone like the sun, and whose understanding and qualities were equally remarkable, and she was named Shaher-ul Beriah (22, p4 of Leyden's translation part).

Similarly, I did not find any physical description of people in Malay Myths and Legends complied and translated by Knappert. In the epic history of Bidasari, a queen gave a birth to "the most beautiful baby you have ever seen" and the description of the baby was "golden all over with a sunny sheen on her skin" (23, p153). In the story of Hang Tuah, there is similar description found. A prince from the Kingdom of Palembang encountered a mysterious girl in the woods who was "with a shining golden color to her skin" (23, p197). The fair skin which is preferred in contemporary Malaysian society does not seem to be one of the elements of beauty in pre-colonial time.

Colonial descriptions of the local people as racial groups have pervaded in the local population. Soda examined the transmission of colonial knowledge by analyzing textbooks used in the systematized Malay vernacular education, and argued that the concept of race was popularized among the people of British Malaya through the education system, mass media and law. Local people were racialized and their nature and capabilities were evaluated in relation to their colonial masters (24, p189). The legacy of British colonial domination and its classification of people into different types with different capabilities and characteristics have been inherited amongst the educated as well. Mahathir's notion of Malays as a "weak race" (25), and the depiction of Malays as less innovative, pleasure-seeking people in Senu Abdul Rahman's Revolusi Mental are just a few examples (26).

\section{Survival of the Concept of Race}

Malaysian people's sentiment of nationalism was developed during the time of Japanese occupation of Malaya until the end of World War II $(27, \mathrm{p} 10)^{10}$. Malaysia achieved independence from the British in 1957 and included Sabah and Sarawak in their federation in 1963. The new state of Malaysia ought to have been engaging in nation-building projects which can be understood as a decolonizing process. Then why has such a nation-state inherited and retained the colonial concept of race? Hirschman stated that even after racist elements have been eliminated from census classification after independence Malaysian society still suffering from "the residue of racial ideology" (16, p570). Why is this concept still surviving in Malaysian society, indeed becoming more prominent than concept of ethnic groups? Farish A. Noor stated that many governments in Africa and Asia including Malaysian that have won their independence against the colonial powers relapsed into "repressive neo-colonial rule" by retaining colonial regulations and system $(28, \mathrm{p} 82)$.

An examination of the caste system in India, for instance, shows that "all the stories about race are to "naturalize' inequality created by society and human being" (29, p347). There are arguments that India's caste system and the word caste itself were invented during the $20^{\text {th }}$ century, the late British colonial period (29-31). Channa argued that before the British colonial period, no concept of caste existed. Instead a status structure called jati or verna was in place, which did not establish a fixed social hierarchy, but rather regulated social stratification with some space for negotiation and contestation. The concept of caste and the caste system were completed by application of the concept of race to the existing local social stratification by the British colonizers. The concept of race which was armed by the science of biology and body measurement made non-rigid traditional social stratification into a fixed and rigid hierarchical system. The Aryan language group has been converted into a racial group and considered superior to the local population. The difference between low caste and high caste are considered to be racial differences ${ }^{11}$. Application of 
race concept to traditional social stratification gave higher caste people and elites some benefits. They could legitimize there superiority and privileges against the lower caste people, thus the caste system and concept were accepted and perpetuated by Indians themselves. In the contemporary discourse on Indian caste, one can find that the stereotyping of physical characteristics is a result of the penetration of the race concept in India (29).

A similar argument can be applied to the case of Malaysia. Retaining the race concept inherited from the British colonial regime gives legitimacy to Malay dominated governments to sustain and protect their positions of power and Malay privileged positions as recognized by the Federal Constitution of Malaysia. The Malaysian Federal Constitution was said to be the result of ethnic bargaining and accommodation amongst the three major ethnic groups. Non-Malays obtained citizenship with the protection of their culture and language while Malays were guaranteed their special position inherited from the British colonial administration (32, p245-6; 33, p33-4). Article 153 of the Federal Constitution charges the monarch to "safeguard the special position" of Malays and other indigenous groups in Malaysia (34, p2). Shad Saleem Faruqi explained that Article 153 indicates the special treatment of Malay and natives of Sabah and Sarawak on the matter of priorities in "the federal public service, scholarships, educational and training privileges or facilities, permits or licenses for the operation of any trade or business" (33, p34).

Safeguarding Malays and other indigenous people's special position has been achieved through a series of policies which can be generally coined as bumiputera policies ${ }^{12}$ Bumiputera means "son of the soil" referring to Malays and other indigenous people such as orang asli, and native people of Sabah and Sarawak (34, p2). Bumiputera policies were developed after the May 13 incident which involved violent clashes between Malays and ethnic Chinese. The alleged cause of the May 13 incident was economic inequality amongst the ethnic groups, and the government of Malaysia carried out New Economic Policies (NEP) to eradicate poverty from Malaysia regardless of ethnic backgrounds and to improve the economic standing of the bumiputera $(34, \mathrm{p} 3 ; 35, \mathrm{p} 36-7)$. NEP was carried out from 1970 to 1990 , followed by National Development Policies to further eradicate poverty. Kubo argues that the intention of NEP was, in reality, to enhance the socio-economic position of Malay people. Especially in education and employment, Malays have been prioritized. There are more Malay students in engineering and medicine. Malay employment in non-agrarian sectors was encouraged and employment in the public sectors has been dominated by the Malays (35, p38-9).

Some Malaysian students indicated that bumiputera policies such as the ethnic quota system made them aware of their ethnic standings in society. Although the ethnic quota system in the universities has been abolished since 2002, students believe that it is still practiced, for instance at the time of university entrance and for scholarship opportunities.
Students claim that Malays as a privileged group can enter universities with lower marks than ethnic Chinese and Indian students while qualified ethnic Chinese and Indian students are not accepted by universities or not able to secure scholarships. The ethnic quota system can be found in various aspects of university life, from the ethnic ratios of professors, university staffs, and students' council members to the number of Malay, ethnic Chinese and Indian restaurants on campus. It is an irony that bumiputera policies, whose goals were to achieve socio-economic equality amongst the population of Malaysia and national unity, are actually deepening gaps amongst the ethnic groups and creating ethnic discontent and antagonism $(35, \mathrm{p} 38 ; 36$, p56-7).

Malay's special position is supported by a series of bumiputera policies, creating and sustaining ethnic hierarchy in Malaysia. By retaining the colonial legacy of race attributed to the three major ethnic groups, the differences amongst these three groups are considered to be biological differences and have become nonnegotiable. Thus the ethnic differences amongst the three are perpetuated, and the privileges of Malays as the genuine race of the tanah Melayu (land of Malay) will not be challenged. Moreover, using the racial argument of Malays as a "gentle race" legitimizes bumiputera policies. Such racial arguments to protect the position of Malays against "stronger races" can be found throughout Mahathir's Malay Dilemma (25).

I also observed internalization of such racial arguments for protection of the Malay race amongst my students. Malay students told me about their experience in Penang. They were ignored and mistreated in ethnic Chinese shops because they believed that they spoke to sellers in Malay language:
"Why don't they speak Malay? This is our land. Why do I need to speak a foreign language (Chinese) in my country? Why are they speaking Chinese but not our national language? The Chinese are obnoxious, and they are invading our land. We (Malays) are too polite to fight against Chinese ${ }^{13}$."

The students' argument based on racial differences, as Malay as polite race while ethnic Chinese as obnoxious race, can lead to the argument to legitimate Malay special position.

The definition of Malay in Article 160 of Malaysian Constitution indicates that the Malay is a person who professes Islam, habitually speaks the Malay language and practices Malay customs. Given the frequent use of this concept of race documented in this paper, it is a striking contrast that the constitutional text does not have any physical definition or condition of descent to determine Malay. It is worth trying to think about why the constitution itself shirks away from a racial definition.

Mohd Arish argued that federal constitutional category of Malays was created "in the political context for purpose of granting economic and political privileges" to the people who can be slotted into the category $(37, \mathrm{p} 9)$. He reported on a group of recent Indonesian migrants who could obtain the 
status of Malay and therefore bumiputera by utilizing the constitutional category of Malay. Many Indonesian migrants are Muslim, speak bahasa Indonesia and can easily adapt Malay customs. He also mentioned the fact that the Malaysian Statistics Department has dropped categories of various Indonesian ethnic groups, Arabs and Indian descent Malay and all have been counted as Malay. During his field research, his informants expressed their discomfort with questions about their ethnic identity. They argued that such a question destroys the unity of the community, and that one should understand that Malays are all the same people (37, $\mathrm{p} 32,41)$. They feared that an ethnic question which may reveal one's mixed heritage with various Indonesian ethnic groups may create divisions and problems amongst the Malay community.

The culturally defined constitutional category of Malay people enables the government to establish a larger Malay reservoir with the people of different ethnic backgrounds which strengthened the political standing of Malay people. The same rational can be applied to those groups who are categorically ambiguous, such as non-Malay (non-Muslim), native populations like orang asli, and various ethnic groups of Sabah and Sarawak. They are often described as ethnic groups and have not been racialized since they could be allied with Malay as the same bumiputera ${ }^{14}$."While applying inherited racialized discourse to bumiputera (Malays) and non bumiputera (ethnic ethnic Chinese and ethnic Indian), the ethnic hierarchy has been successfully established in Malaysia, and racialized ethnic relationships will maintain this rigid social hierarchy based on the racial differences just like the caste system $(37, \mathrm{p} 9)$.

The race concept entrenches differences within the population, serving as a useful tool to divide people and maintain privileges. Survival of the colonial concept of race in post-independent Malaysia is not a natural development that comes with ethnic diversity but result of a political intention.

\section{Conclusions}

It will take a considerable effort to shake off racialized discourse and eradicate racial categorization from the minds of people in Malaysia. Goldberg defined race as racialized discourse and stated that the function of this concept can be interpreted as follows:

(Race) has established who can be imported and who exported, who are immigrants and who are indigenous, who may be property and who citizens; and among the latter who get to vote and who do not, who are protected by the law and who are its objects, who are employable and who are not, who have access and privilege and who are (to be) marginalized. Race continues to assume significance in this complex way $(38, \mathrm{p} 87)$.

Hirschman defined the concept of race is real only on the base of racism. People are still discriminated on the base of assumed race and in such context race is real though classification of human population into racial categories is flawed (39, p407-9)

It is a paradox that a country which has carried out a series of national unity and integration projects such as bangsa Malaysia under Mahathir and the recent One Malaysia campaign has retained the concept of race and been racialising its population. As long as the concept of race persists in understandings of inter-group relationships, national integration will remain elusive. University students who introduce themselves to me, a foreign lecturer, as Malaysian-Chinese or Malaysian-Indian instead of Chinese-Malaysian or Indian-Malaysian reflect how national integration projects have little effect on their mind.

There is no such thing as race in Malaysia, but rather racialized and hierarchical ethnic relationships. The racialized discourse turns ethnic boundaries into unchangeable biological boundaries. This is what Homi K. Bhabha described as "the concept of fixity in the ideological construction of otherness" and it is the "important feature of colonial discourse" (40, p18). In order to build inclusive national discourses, and to achieve national integration, Malaysia needs to abandon its colonial vestiges.

This study was started with a very simple question: "why don't my students stop using the term race?" which led me to examine Malaysian state policies and further its colonial legacy. The race concept in Malaysia which was introduced by the British colonial government hierarchized local population along their ethnic differences. Malaysia sate which gained its independence from the British has retained such hierarchy to secure political domination of a certain ethnic groups. The selective adaptation of the colonial legacy can be understood as its strategy of the state's manipulation for the power. My study could demonstrate that the concept of race can be seen as a strategy for obtaining, sustaining and perpetuating the power. In this sense this study would affirm the argument that the race is not a scientific term or concept but it is a political strategy.

\section{Notes}

1. The first Ethnic Relations course was taught in Universiti Putra Malaysia (UPM) in 2006. A textbook prepared by two UPM lecturers for this course was criticized as biased and insensitive especially about the accounts of ethnic crash on the May 13, 1969 and the kampong Medan incidents (41). The controversy of UPM's textbook was raised in parliament and Lim Kit Siang, the chair of Democratic Action Party, an opposition party of Malaysia, accused this textbook as "tendentious, divisive and mischievous"(42). The UPM finally withdrew the textbook, and the Ministry of Higher Education formed a committee to come up with a new textbook. There was a discussion if the government's intervention for Ethnic Relations 
textbook could be seen as a sign of loosing of universities' academic autonomy (43)

2. The problems of defining ethnic groups as cultural groups have been pointed out in 1960s by the works like M. Moerman's “who are the Lue?" and E. Leach's classical work, Political systems of the highland Burma (44-45). It has been agreed amongst anthropologists that ethnic groups cannot be defined by culture.

3. In the survey, there are two questions: 1) which one of the following groups you consider as a racial group? Please circles as many as you identify as a racial group 2 ) which one of the following groups you consider as an ethnic group? Please circle as many as you identify as an ethnic group. The same names of 34 groups were provided to be classified as a racial group or an ethnic group. The valid responses from students counted 145 and from faculty members counted 17.

4. I used English articles since there is no Malay equivalent to the term "race". The Malay word bangsa which is translated as race is also used to indicate an ethnic group, and a nation.

5. There were 30 articles which talked about the ethnic relationships outside of Malaysia. These articles were not included in the sample

6. There are various discussions on marginalization of indigenous population in the bumiputera system. See C. Nicholas (46) and T. Nobuta (47).

7. The Association of American Anthropologists, for instance, released statements in 1994 and 1998 to denounce the concept of race:

http://www.aaanet.org/stmts/race.htm and

http://www.aaanet.org/stmts/racepp.htm

8. Another three points are as follows: 1) each ethnic group in Malaysia is not homogeneous; there are political, economical and social differences amongst them. 2) The ethnic relations in Malaysia are not based on the population size, in other words, majority-minority relationships. Rather, they are based on degrees of power and influence. 3) Despite existing ethnic discontent there is no major ethnic violence in Malaysia (10, p2-3).

9. Munshi Abdullah, the author of Hikayat Abdullah was known as the first journalist in Malay language. He was born in Malacca in the late $18^{\text {th }}$ centuries, and had Arab and Indian ancestry. He spoke Arabic, Malay and Tamil and became a translator and teacher of colonial officer for Dutch and British. He was known for his works for Sir Stamford Raffles (19). Because of his close affiliation with the British officials, he seemed to have adapted the notion of race as biological classification of people.

10. The permanent exhibition of modern Malaysian history at the National Museum in Kuala Lumpur shows a documentary film of Malaysia under British and Japanese occupation. While British occupation was depicted somewhat positively by bringing education to Malaysia (despite making people suffer and experience poverty), Japanese occupation was depicted as causing total destruction of the communities. It further explained that people of Malaysia under the British could not be united, however under Japanese harsh and brutal occupation people were united to protect their homeland.

11. Several ethnic Indian students in my courses indicated similar belief of the relationship between caste and skin color; the dark skin Indians belong to the lower caste while the fair skin Indians belong to the upper caste.

12. The Malaysia government has never used the term bumiputera policies officially $(35, \mathrm{p} 37 ; 34, \mathrm{p} 1 ; 48$, p103).

13. I was occasionally visited various students who poured out their frustration over government ethnic policies or their resentment toward other ethnic groups in my office. I found a discrepancy between what my students feel and what they say. The most often repeated expression on ethnic relations in their assignments was: "Malaysia is unique because we have many different races such as Malay, Chinese and Indian, and we live together in harmony and peace". My experiences at the university made me wonder about the level of national integration of Malaysia, which has motivated me to write this paper.

14. For instance, a book titled "Representation, identity and Multiculturalism in Sarawak", edited by Zawawi Ibrahim, published in 2008 consisted of fifteen chapters does not use the word "race" to indicate ethnic relationship in Sarawak (49).

\section{REFERENCES}

[1] Willford A. Cage of freedom: Tamil identity and the ethnic fetish in Malaysia, Ann Arbor, MI: the University of Michigan Press; 2006.

[2] Shamsul A. B. Many ethnicities, many cultures, on nation: The Malaysian experience UKM Ethnic Studies Papers No. 2 (November). Kuala Lumpur: Institute of Ethnic Studies, Universiti Kebangsaan Malaysia; 2008.

[3] Martinez P. Southeast Asian affairs. Singapore: Institute of Southeast Asian Studies; 2005.

[4] Kinloch G. The dynamics of race relations. New York, Dusseldorf: McGraw-Hill;1974.

[5] Barkan E. The retreat of scientific racism: Changing concepts of race in Britain and the United States between the world wars. New York and Melbourne: Cambridge University Press; 1992.

[6] Banton M. Racial theories, $2^{\text {nd }}$ ed. Cambridge: Cambridge University press; 1998.

[7] Banton M. The Idiom of race In: Back L, Solomos J. editors Theories of Race and Racism: A Reader. New York: Routledge; 2000. 
[8] Takezawa Y. Hyosho kara jinshu no shakaiteki riariti o kangaeru (Racial representation and social reality of race). In: Takezawa Y, editor. Jinshu no hyosho to shakaiteki riariti (Racial representation and social reality of race). Tokyo: Iwanamishoten; 2009.

[9] Takezawa, Y. Jinshugainen no hokatuteki rikai nimukete (Toward comprehensive understanding of the concept of race). In: Takezawa Y, editor. Jinshugainen no fuhensei o tou: Seiyoteki paradaimu o koete (Questioning universality of the concept of race: Beyond the Western paradigm). Tokyo: Jinbunshoin; 2005.

[10] Syed Husin Ali. Ethnic relations in Malaysia: Harmony \& conflict. Petaling Jaya: Strategic Information and Research Development Centre; 2009.

[11] Ye Lin-Sheng. The Chinese dilemma. Australia: East west Publishing Pty Ltd; 2003.

[12] Sundram J. M. A. Race, class and uneven development in Malaysia. MA thesis. Department of Sociology at Michigan State University; 1983.

[13] Milner A. Ideological wrok in constructing the Malay majority. In Gladney $\mathrm{D}$, editor. Making Majorities: constituting the Nation in Japan, Korea, China, Malaysia, Fiji, Turkey and the United States, Stanford, CA: Stanford University Press; 1998.

[14] Milner A. The invention of oolitics in colonial Malaya, $2^{\text {nd }}$ ed. Cambridge, New York, Melbourne, Madrid and Cape Town: Cambridge University Press; 2002.

[15] Milner A. Afterword: A history of Malay ethnicity. In Barnard T, editor. Contesting Malayness: Malay identity across boundaries. Singapore: Singapore University Press; 2004.

[16] Hirschman C. 'The meaning and measurement of ethnicity in Malaysia: An analysis of census classifications. JAS. 1987: 46 ( 3): $555-82$

[17] Hirschman C. The making of race in colonial Malaya: Political economy and racial ideology. Sociol Forum. 1986. 1(2): 330-61.

[18] Syed Hussein Alatas. The Myth of the lazy native: a study of the image of the Malays. Filipinos and Javanese from the $16^{\text {th }}$ to the $20^{\text {th }}$ century and its function in the ideology of colonial capitalism. London and New York:Routledge, 2010.

[19] Abdullah Bin Abdul Kadir. Hikayat Abdullah Trans. by A. H. HILL. Kualal Lumpur, Singapore, London and New York: Oxford University Press; 1970.

[20] Winstedt R. Malaya and its history. $7^{\text {th }}$ ed, London: Hutchinson University library; 1966.

[21] Milner A. Localizing the 'Bangsa Melayu'. In: Kawashima $M$, editor. Proceedings of the symposium on Bangsa and Umma: A comparative study of people-grouping concepts in the Islamic areas of Southeast Asia. Japan: Section for Islamic area studies, Institute of Asian Cultures, Sophia University; 2007.

[22] Hooker VM, Hooker MB. John Leyden's Malay Annals / with introductory essay by Virginia Matheson Hooker and M. B. Hooker. Kuala Lumpur: MBRAS; 2001.

[23] Knappert J. Malay myths and legends. Kuala Lumpur, Singapore and Hong Kong: Heinemann Educational Books
(Asia) LTD; 1980.

[24] Soda N. The Malay world in textbooks: The transmission of colonial knowledge in British Malaya. Tonan Ajia Kenkyu (Southeast Asian Studies). 2002; 39:188-234.

[25] Mahathir Mohamad. The Malay dilemma, Kuala Lumpur: Federal Publications; 1970.

[26] Senu Abdul Rahman. Revolusi mental (Mental Revolution). Cheras and Kuala Lumpur: Utusan Publications \& Distributors; 2002.

[27] Hooker V. A short history of Malaysia: Linking East and West. Chiang Mai: Silkworm Books; 2003.

[28] Farish A.Noor. What your teacher didn't tell you. Petaling Jaya: Matahari Books; 2009.

[29] Channa S. Indo niokeru kasuto jinshu shokuminchishugi: Shakaitunen to seiyoukagaku no sogosayo (Caste, race and colonialism in India: Interaction of social convention and Western sciences). In: Takezawa Y. editor. Jinshu no hyosho to shakaiteki riariti (Racial representation and social reality of race). Tokyo: Iwanamishoten; 2005. p.321-355.

[30] Chatterjee P. The nation and its fragments: Coonial and post colonial histories. Princeton, NJ: Princeton University Press; 1993.

[31] Hobson K. Ethnographic mapping and the construction of the British census in India, [ Internet] . britishempire.co.uk. UK: Luscombe S.1996; [cited 2010 March 19]. Available from: http://www.britishempire.co.uk/article/castesystem.html

[32] Tan Chee Beng. Ethnic dimension of the constitution. In: Reflections on the Malaysian constitution. Penang: Aliran Kesedaran Negara, 1987. Ch.9 of Aliran, Relections on the Malaysian Constitution (Penang, Aliran,1987)

[33] Shad Saleem Faruqi. Affirmative action policies and the constitution. In: Mason R, Ariffin Omar editors. The 'Bumiputera policy': dynamics and dilemmas Kajian Malaysia. Journal of Malaysian Studies special issue. 2005:21( $1 \& 2)$. P31-57.

[34] Mason R, Ariffin Omar. The Bumiputera policy:Dynamics and dilemmas. In: Mason R, Ariffin Omar editors. The 'Bumiputera policy': dynamics and dilemmas Kajian Malaysia. Journal of Malaysian Studies special issue. 2005:21( $1 \& 2)$.

[35] Kubo C. Mareshia no bumiputora seisaku (Malaysia's Bumiputera policies). [ Internet] [Place unknown]: [Publisher unknown] 2003[cited 2009 July 7]. Available from: http://www.edu.nagasaki-u.ac.jp/private/tanigawa/seminar/gr aduation/2003/kubo/MALAYSIA.pdf

[36] Zakaria Haji Ahmad, Suzaina Kadir. Ethnic conflict prevention and management: the Malaysia case. In: Kasuma Snitwongse, Thompson W. S. editors. Ethnic conflicts in Southeast Asia. Institute of security and international studies, Chulalongkon University, Thailand, Institute of Southeast Asian Studies: Singapore; 2005.

[37] Mohd Arish Hj Othman. The Dynamics of Malay Identity, Monograph 7 . Kuala Lumpur: Fakuliti Sains Kemasyarakatan dan Kemanusiaan Universiti Kebangsaan Malaysia; 1983.

[38] Goldberg D. Racist culture: Philosophy and the politics of 
meaning. Oxford: Blackwell; 1993.

[39] Hirschman C. The origins and demise of the concept of race. In Popul Dev Rev. 2004; 30 ( 3): 385-415.

[40] Homi K. Bhabha. The other question: difference, discrimination and the discourse of colonialism. Screen 1983; 24 ( 6):18-36.

[41] Husna Yusop. Students: Course on ethnic relations benefited us". In Sun2Surf: Malaysian Source for News \& Lifestyle, 10 August 2006. [Internet] [Place unknown]: [Publisher unknown] 2006 [cited 2010 August 9]. Available from http://sun2surf.com/article.cfm?id=15067

[42] Lim, Kit Siang. "Grave defect of revised "ethnic relations" module - no proper public feedback and consultation as the draft was also withheld from parliamentary select committee on national unity. (media statement on 2007 January 25) [Internet]. [Place unknown]: DAPMalaysia.org: [Original Publication Date unknown] [cited 2009 June 10]. Available from: http://www.dapmalaysia.org/english/2007/jan07/lks/lks4167. htm .

[43] Ras Fg Ha. "Ethnic relations module has no bearing on universities' autonomy”, Bernama News, 24. February 2007.
[44] Leach E. R. Political systems of highland Burma: A study of Kachin social structure. London School of economics Monographs on Social Anthropology No. 44. London, and Atlantic Highlands, NJ: The Athlone Press;1964.

[45] Moerman M. Ethnic Identification in a Complex Civilization: Who Are the Lue? Am Anthropol. 1965; 67:1215-30.

[46] Nicholas C. The Orang Asli and the contest for resources; Indigenous politics, development and identity in Peninsula Malaysia. Kuala Lumpur: IWGIA/ Center for Orang Asli Concerns; 2000.

[47] Nobuta, T. Living on the periphery: Development and Islamization among the Orang Asli in Malaysia. Subang Jaya, Malaysia: Center for Orang Asli Concerns; 2009.

[48] Onozawa J. Mareshia no Najibu shinseiken to Bumiputora seisaku no yukue (Najib'sNew government and future of Bumiputera policies). Kikan kokusaiboeki to toshi (International trade and investment Qurterly). 2009; 77:87-105.

[49] Zawawi Ibrahim. Representation, identity and multiculturalism in Sarawak. Kuala Lumpur: Dayak Cultural Foundaiton and Persatuan Sains Social Malaysia; 2008. 